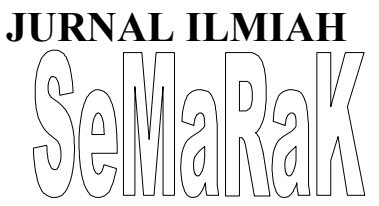

\title{
KINERJA SATUAN POLISI PAMONG PRAJA (SATPOLPP)KECAMATAN SERPONG DALAM PENERTIBAN PEDAGANG KAKILIMA(PKL)DI PASAR SERPONG
}

\author{
Rahmi Andini Syamsuddin \\ Dosen Fakultas Ekonomi Universitas Pamulang \\ Email : dosen02062@unpam.ac.id
}

\begin{abstract}
ABSTRAK
Tujuan dari penelitian ini adalah untuk mengukur kinerja Satpol PP Kecamatan Serpong dalam penertiban PKL di Pasar Serpong. Dalam penelitian ini menggunakan jenis deskriptif kualitatif dengan menggunakan metode pengumpulan data melalui wawancara, observasiserta dokumentasi. Peneliti akan mengunakan indikator antaralain : effectiveness, responsiveness, responsibility, accountabilitydalam mengukur kinerja dari SatpolPP Kecamantan Serpong. Hasil yang didapat dalam penelitianini menunjukkan masih ada indikator kinerja yang masih kurang baik yaitu pada indikator effectiveness. Untuk 3 indikator lainnya sudah baik seperti pada indikator responsibility, Unit SatpolPP Kecamatan Serpong telah melakukan sosialisasi kepada PKL di Pasar Serpong. Selanjutnya untuk indikator responsivitas, hasil terhadap kinerja SatpolPP Kecamatan Serpong sudah baik berdasarkan pengukuran pada keluhan,kritikdansaran yang diterma dengan baik oleh SatpolPP kecamatan Serpong. Indikator terakhir adalah accountability, hasilnya adalah sudah baik. Hal ini dapat diketahui bahwa dalam menjalankan penegakkan Peraturan Daerah, SatpolPP Kecamatan Serpong sudahberjalan dengan mutu yangbaik, kisaran waktu yang sesuai serta prosedur/tata cara yang tidaksulit dipahami oleh masyarakat.
\end{abstract}

Kata Kunci : kinerja, Satuan Polisi Pamong Praja, Pedagang Kaki lima

\begin{abstract}
The purpose of this study was to measure theperformance of Civil Service PoliceUnit in Serpong District in controlling streetvendors in Serpong Market. This research is using descriptive qualitative with interview, observation and documentation techniques as a method to collecting data. In this study researchers will use indicators, among others: effectiveness, responsiveness, responsibility, accountability in measuring the performance of Civil Service PoliceUnit. Based on the results of the research, it can be concluded that there are still poor performance indicators, namely
\end{abstract}




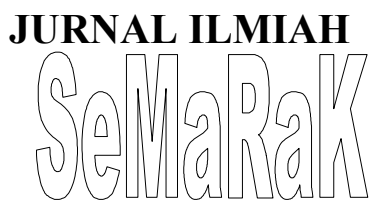

the effectiveness indicator. For the other 3 indicators, it has been good, as in the indicator of responsibility, Civil Service Police Unit in Serpong Sub-District has conducted socialization to street vendors in Serpong Market. Furthermore, for indicators of responsiveness, the resultsof the performance of the SatpolPP Subdistrict in Serpong have been good based on the measurement of complaints, criticisms and suggestions that were received well by Civil Service Police Unit in the Serpong sub-district. The last indicator is accountability, the result is good. It can be seen that in carrying out the enforcement of Regional Regulations, Civil Service Police Unit Serpong Subdistrict runs in accordance with good quality, precise time estimates and procedures that are easily understood by the community.

\section{Keywords: performance, Civil Service Police Unit, Street Vendors}

\section{PENDAHULUAN}

\section{A. Latar Belakang}

Saat ini terjadi ketidakmerataan antara pembangunan kota dan pembangunan desayang mana menyebabkan terjadinya perpindahan penduduk dari desake kota yang mana biasa disebut dengan urbanisasi. Dari perpindahan ini menimbulkan berbagai dampak pada daerah/lokasi yang didatangi, baik dampak positif maupun dampak negatif.Sebagiandaripendudu yang tidak suksesmasuk ke dalam kegiatan sektor formal akan berusaha untuk memasukikegiatan sektor informa. Hal ini diakibatkan karena sektor informal merupakan sector yang mana tidak sulit untuk dimasuki oleh siapapun tanpa adanya suatu keterampilan khusus. Sebagian besar yang menggeluti sektor ini adalahberasal dari kalangan bawah, yaitu mereka yang tidak dapat masuk ke sektor formal dan juga mereka yang tidak ingin berhubungan denga penguasaan kaum kapitalis yang telah menguasai perekonomian yang bersifatmakro.

Menurut Hidayat (2010:17), "sektor informal diartikan sebagai unitunit usaha yang tidak atau sedikitsekali menerima proteksi ekonomi secararesmi dari pemerintah." Sektor informal ini umumnya berupa usahaberskala kecil dengan modal, ruanglingkup dan pengembangan yangterbatas, contoh dari sektorinformal tersebut adalah Pedagang Kakilima (PKL). Keberadaan PKL merupakan salahsatu jenis usaha pada sektor informal, sebagai pilihan lain dalam lapangan pekerjaan bagi kaumurban. Lapangan pekerjaan yang semakin berkurang 
menjadi penyebab semakin banyaknya masyarakat yang memilih untuk memiliki mata pencaharian sebagai pedagang kakilima.

Pada beberapa kota diIndonesia, keberadaan PKL merupakan dilema dan masalah laten yang tidakhanya menimbulkan pro-kontra, demontrasi, bentrok antar warga maupun antara warga dan aparat. Dalam kaitan tersebut maka perlu dilakukan penataan PKL secara bijaksana untuk dapat menata sebuah ruang publik yang optimal yang memadai baik dari segi kualitas maupun kuantitas. Oleh karena itu perlu adanya suatu penataan yang dilakukan olehpetugas atau aparatur pemerintahan untuk menangani masalah-masalah tersebut, yang mana telah diamanatkan dalam pasal 148 ayat (2) Undang-undang Nomor32 Tahun 2004 tentang PemerintahanDaerah yang isinya "SatpolPP adalah perangkat daerah yang membantu tugas kepala daerah dalam menegakkan Perda danketentraman masyarakat yang dikepalai oleh kepaladaerah".

Peran Satpol PP dlam menegakkan Perda sangat berhubungan dengan adanya pelanggaran Hak Asasi Manusia (HAM) pada saat dilakukan proses pentertiban dan bagaimana bentuk pengawasanya terhadap Perda yang dijalankan sesuai dengan Tugas Pokokdan Fungsinya sebagai apparat penegak perda dan penyelenggaraan ketertiban umum dan ketentraman masyarakat.Untuk itu, sesuai dengan tugasdan fungsi Satpol PP Kota Tangsel dibekali Peraturan Daerah (Perda) No. 9 Tahum 2012 tentang Ketertiban umum. Salah satunya adalah penertiban PKL yang menyalahi aturan dan Perda No. 8 tahun 2012 tentang Penataan dan Pemberdayaan PKL.

Sesuai dengan Tugas Pokok dan Fungsi SatpolPP kecamatan Serpong maka SatpolPP kecamatan diharapkan dapat menjalankan penertiban Perdamelalui pendekatan persuasi yang lebih mendidik, sehingga ketika menghadapi situasiapapun, SatpolPP dapat mengambil sikap yang tepatdan bijaksana. Dapat menjadi aparat yang ramah,bersahabat dan dapat menciptakan suasana kesejukkan bagi masyarakat, namun tetap tegas dalam bertindak sesuai dengan peraturan yang berlaku.

Selain itu,pihak Satpol PP dituntut agar dapat bekerja secara professional. Menurut Kusnandar, "profesioalisme merupakan sebutan yang mengacupada sikapmental dalam bentuk komitmen dari para anggota profesi untuk mewujudkan dan meningkatkan kualitas profesionalnya." Profesionalisme menjadi komitmen daripara anggota profesi untuk meningkatkan kemampuan profesionalny dan secara berkala 
strategistrategi yang digunakan dlam melakukan pekerjaan sesuai profesinya. Unit Satpol PP dinyatakan profesional apabila dalam melakukan pekerjaannya sesuaidengan prosedurkerja yang telah ditetapkan dandinyatakan tidak profesional bila tidak sesuai dengan prosedur kerja yang telah ditetapkan.

Terciptanya efektifitas peran SatpolPP di Pasar Serpong, Kecamatan Serpong tidak lepas dari berbagaikerjasama yang baik dari berbagai bagian di dalam instansipemerintah itu sendiri dimana koordinasi adala bagian yang tidak lepas darisebuah organisai. Terdapat beberapa kendala dalam penanganan PKL di Pasar Serpong antara lain masih lemahnya koordinasi antara SatpolPP Kota Tangsel, kecamatan, kelurahan dan Badan Pengelola Pasar dalam hal menertibkan PKL di Pasar Serpong serta dalam pelaksanaan kegiatan terkadang informasi mengenai tugas masing-masing tidak tersosialisasi dengan baik.

Berdasarkan permasalah di atas, maka penulisinginmembuat penelitian denganjudul : "Kinerja Satuan Polisi Pamong Praja (SatpolPP) Kecamatan Serpong Dalam Penertiban Pedagang Kakilima (PKL) di Pasar Serpong”.

\section{B. Perumusan Masalah}

Berdasar pada latarbelakang tersebut, maka dapat dirumuskan beberapa masalah yang antara lain :
1. Bagaimana kinerja SatpolPP Kecamatan Serpong dlam penertiban PKL di Pasar Serpong?

2. Bagaimana upaya-upaya yang dilakukan oleh SatpolPP Kecamatan Serpong dalam penertiban PKL di Pasar Serpong?

\section{Tujuan Penelitian}

Berdasarkan rumusan masalah diatas, maka tujuan dari penelitianini adalah :

1. Agar dapat mengetahui dan menganalisis secara deskriptif bagaimana kinerja SatpolPP Kecamatan Serpong dalam upaya penertiban PKL di Pasar Serpong.

2. Agar dapat mengetahui dan menganalisis secara deskriptif bagaimana upaya yang dilakukan oleh SatpolPP Kecamatan Serpong dalam penertiban PKL di Pasar Serpong.

\section{TINJAUAN PUSTAKA}

\section{A. Definisi Kinerja}

Salah satu aspekyang menentukan keberhasian suatu organisasi adalah kinerja dariorganisasi itu sendiri. "Kinerja merupakan hasilkerja yang dicapai oleh suatu organisasi atau pegawai dalam melaksanakan tugas\&tanggungjawabnya." Istilah kinerja sering digunakan untuk menyebut prestasi atautingkat 
keberhasilan dariindividu ataupun kelompokindividu (organisasi).

"Kinerja (performance) adalah suatu pencapaia persyaratan perkerjaan tertentu yang akhirnya secara nyata dapat tercermin keluaran yangdihasilkan."Kinerja merupakan salah satu alatukur bagi pencapaian tujuan organisasi. Hasibuan (2002) juga mendefinisikan "kinerja (prestasi kerja) sebagai hasil kerja berupa kualitas dan kuantitas yang dicapai oleh seorang pegawai dalam melaksanakan tugasnya sesuai dengan tanggungjawab yang diberikan kepadanya."Rivai (dalam Muhammad Sandy, 2015:12) mendefinisikan bahwa "kinerja/prestasi adalah hasil atau tingkat keberhasilan seseorang secara keseluruhan selama periode tertentu dalam melaksanakan tugas dengan berbagai kemungkinan seperti standar kerja, target atau sasaran serta kriteria yang telah ditentukan terlebih dahulu dan disepakati bersama."Menurut Mahsun (2009:25) "Kinerja (performance) adalah gambara mengenai tingkat pencapaian pelaksanaan suatukegiatan / program / kebijakan dalam mewujudkansasaran, tujuan, misi danvisi organisasi yang tertuang dalam strategicplanning suatu organisasi."

Istilah kinerja banyak digunakan dalam menyebut prestasiatau tigkat keberhasilanindividu atau kelompok individu. Kinerja bisa diketahui bilaseseorng atau kelompok individu tersebut memiliki kriteria keberhasilan yang telah ditetapkan. Kriteria keberhasilan ini berupa tujuan - tujuan atau target-target tertentu yang hendak dicapai. Tanpa ada tujuan atautarget, kinerja seseorang atau organisasi tidak mungkin dapat diketahui karena tidak ada tolakukurnya.

\section{B. Indikator Kinerja}

Menurut Dwiyanto, dkk. "kinerja organisasi dalam birokrasi publiksecara lengkap dapatdilihat melalui beberapa indikator", antaralain :

1. Produktivitas

Indikator produktivitas tidak hanya mengukur tingkatefisiensi tetapi jugaefektivitas pelayanan. Produktivitas secara umum dipahami sebagairasio antara masukan dengan keluaran.

2. Kualitas Layanan

Indikator Kualitas layanan menjadi sangat penting, hal ini disebabkan karena adanya pandangan negatif mengenai organisasi publik. Hal itu muncul karena adanya ketidakpuasan masyarakat terhadap kualitas layanan yang diterma dari organisasi publik. Karena itu, kepuasan masyarakat terhadap layanan bisa menjadi indikator kinerja dalam organisas publik.

3. Responsivitas 


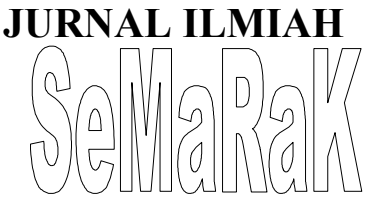

Indikator

merupakan

Responsivitas

organisasi dalam memenuhi

kebutuhan

masyarakat,

menyusun agenda dan priorits

pelayanan dan pengembangan

program -program pelayanan

publik sesuai dengan

kebutuhandan aspirsasi

masyarakat. Responsvitas masuk sebagai salah satu indicator kinerja sebab responsvitas secara langsung memberi gambaran mengenai kemampuan organisasi publikdalam menjalankan misi dan tujuannya, terutama dalam memberi kebutuhan masyarakat.

4. Responsibilitas

Indikator

Responsibilitas

memberi penjelasan mengenai bagaimana pelaksanaan kegiatan organisasi publikitu dilakukan, apakah sudah sesuai dengan prinsip-prinsip administrasi yang benar atau sudah sesuaidengan kebijakan organisasi, baik yang tertulis maupun yang tidak tertulis.

5. Akuntabilitas

Indikator Akuntabilitas publik menunjukkan seberapa besar kebijakan dan kegiatan organisasi publik tunduk pada para pejabatpolitik yang dipilih oleh rakyat. Kinerja organisasi publik tidak hanya bisa dilihat dariukuran internal yang dikembangkan oleh organisasi publik atau pemerintah, seperti pencapaian target. Kinerja sebaiknya harus dinilai dari ukuran eksternal, seperti nilainilaidan norma yang berlaku di masyarakat. Suatu kegiatan organisasipublik memiliki akuntabilitasyang tinggi kalau kegiatan itu dianggap benar dan sesuai dengan nilaidan norma yangberkembang di dalam masyarakat.

Dari berbagai aspek diatas, maka pada penelitianini peneliti menggunakan indikator antaralain : effectiveness, responsiveness, responsibility, danaccountability. Alasa dlma pemilihan dindikator efektivitas, adalah peneliti ingin mengetahui apakah tujuandari Unit SatpolPP Kecamatan Serpong telah tercapai. Dengan indikator efektivits ini diharapka kegiatan yang dilakukan oleh Satpol PP dapat diketahui.Selain indikator efektivtas, peneliti juga memilih indikato responsibilits, indikator responsivitasdan indikator akuntabilitas dengan alasanbahwa indikator trsebut dapat mengambarkan proses kegiatan yang akan dilakukan oleh Unit SatpolPP Kecamatan Serpong dalam upaya mencapai tujuan.

Indikator diatas dipilih karena dianggap bahwa indikator-indikator 
tersebut dapat memberi kemudahan peneliti dalam mengukur dan menilai kinerjaSatpolPP Kecamatan Serpong dalampenertiban PKL Pasar Serpong. Selain daripadaitu, indikator-indikator tersebut mampu mewakilidan menggambarkn pelaksanaan kegiatankegiatan yang dilakukan oleh unit Satpol PP dalam pencapaian tujuan organisasinya.

\section{Satuan Polisi PamongPraja (SatpolPP)}

Berdasarkan PP Nomor 6 tahun 2010 Pasal 3 tentang Satpol PP, pengertian SatpolPP adalah sebagai berikut : "Satpol PP merupakan bagia perangkat daerah dibidang penegakan Peraturan Daerah, ketertiban umum dan ketentraman masyarakat". Lebih lanjut, "Satpol PP bertugas membantu kepaladaerah dalam menciptakan kondisi daerah yang tentram, tertib dan teratur agar dalam penyelenggaraanroda pemerintahan bisa berjalan dengan lancar dan masyarakatpun dapat melakukan kegiatan meraka dengan lebihaman." Oleh karenaitu, selain menegakan Perda, SatpolPP juga dituntut untuk menegakan kebijakan pemerintah daerah lainnya yaitu peraturan kepala daerah. Pada dasarnya, seorang anggota SatpolPP adalahseorang apparat polisi, yang manamerupakan (bahkanharus) dimasukkan ke dalam bagian dari aparat penegak hukum (lawenforcer). Hal tersebut dikarenakan Satpol PP dibentuk dalam rangka membantu tugas kepala daerah khususnya dalam menegakkan peraturan daerah (Perda). Sebagaimana diketahui, Perda menurutPasal7 ayat (1) UU Nomor10 Tahun2004 tentang Pembentukan Peraturan Perundangundangan yang termasuk dalam salahsatu jenis perundang-undangan.

Tugas dan Fungsi dari Satpol PP sebagai aparat penegak Perda dinyatakan dalam Pasall buti r8, Pasal2 ayat1 Peraturan Pemerintah Nomor6 Tahun 2010 tentang Satuan Polisi PamongPraja. Pada kedua pasal tersebut pada dasarnya menyatakan eksistensi Satpol PP sebagai bagian dari perangkat daerah yang dibentuk dalam rangka membantu kepala daerah dalam menegakan Peraturan Daerah dan menyelenggarakan ketertiban umum serta ketertiban masyarakat. Pasal3, dan 4 PP Nomor 6 Tahun 2010 tentang Satuan Polisi Pamong Praja. Dari pengertian diatas, Satpol PP mempunyai fungsi \& tugas dalam rangka membantu Walikota dalam menyelenggarakan pemerintahan daerah khususnya dibidang ketentraman dan ketertiban umumdan jugadalam hal penegakan peraturandaerah. Hal ini membuat peran Satpol PP menjadi sangat penting yaitu sebagai aktor dalam implementasinyayaitu dalam rangka penegakanperaturan daerah dan mewujudkan ketertiban umum dan 
ketentraman umum"menurut Rustopo, dkk.(2009:58). Dengan tugas dan wewenangyang diberikan SatpolPP, maka SatpolPP dibentuk bertujuan agar kesadaran masyarakat tumbuh sehingga dalam penyelenggaraanusahanya (PKL) tidak mengganggu ketertibanumum, kebersihan lingkungan kota akan terjaga dan lalulintas di sekitarnya juga akan lancer. Oleh karenaitu keberadaan PKL perlu diaturdan dibina sehingga dalam pemanfaatan tempat usaha akan sesuai dengan dalam peruntukannya dalam tataruang yang telahditetapkan.

\section{Pedagang Kaki Lima}

Istilah kaki lima berasal dari masa penjajahan colonial Belanda, yang mana dalam peraturan pemerintah menetapkan setiap jalan raya yang telah dibangun sebaiknya juga menyediakan sarana dan prasarana bagi pejalanan kaki. Lebarruas untuk pejalankaki adalah limakaki atausekitar satu setengah meter.Namun pada kenyataannya, setelah Indonesia merdeka banyak ruas jalan yang sebenarnya ditujukan untuk pejalan kaki malah banyak dimanfaatkan oleh pedagang untuk berjualan. Istilah untuk pedagang tersebut adalah "pedagang emperan jalan" akan tetapi sekarang menjadi "pedagang kakilima". Terdapat beberapa pengertian tentang pedagang kaki lima, menurut Kamus Besar
Bahasa Indonesia Kontemporer (1991), "Pedagnag Kaki Lima adalah pedagang yang menjual barang dagangannya dipinggirjalan atau dalam usahanya menggunakan sarana dan perlengkapan yang mudah dibongkarpasang atau dipindahkan." Selain itu, masih banyak jugayang menggunakan bagianjalan atau trotoar yang merupakan tempat-tempat yang tidak diperuntukkan bagitempat untuk berusaha ataupun tempat lain yang pada dsarnya bukan miliknya.

Mereka yang masukdalam kategori pedagang kakilima ini mayoritas berada dalam usia kerja utama (prime-age). Soemadi (1993:26) menyatakan bahwa "pedagang kaki lima memiliki tingkat pendidikan yang rendah dan tidak adanya keahlian tertentu membuat mereka sulit dalam menembus sektor formal." Keberhasilan pedagang kakilima itu sendiri akan ikut menentukan peranan dalam pembangunan ekonomi daerah dimana pembangunan ekonomi daerah ini merupakan indikator yang akan diukur tentang seberapa besar konstribusi angkatan kerja yang terserap pada sektor informal.

Melihat dari beberapa pengertian yang diungkapkan oleh para ahli tersebut, maka dapat disimpulkan bahwa "pedagang kaki lima adalah orang-orang yang menjajakan barang dan jasa agar dapat dijual pada tempat 
yang pada dasarnya merupakan ruang untuk kepentingan umum, contohnya seperti dipinggir jalan, ruang kosong yangramai serta di trotoar."

\section{E. Kinerja Satuan Polisi Pamong Praja (Satpol PP) Kecamatan Serpong Dalam Penertiban Pedagang Kakilima (PKL)}

Dari pengertian mengenai kinerja tersebut maka dapat disimpulkan bahwa "kinerja (performance) adalah merupakan pencapaian atau hasil kerja dari sebuah organisasi atau perusahaan dalam jangka waktu tertentu." Penilaian dari kinerja ini adalah dengan menilai seberapa jauh organisasi atau perusahaan dalam melaksanakan tugasnya sesuai dengan target atau sasaran yangtelah ditentukan sebelumnya atau kesesuaian pelaksanaan tugas dengan visimisi yang diemban oleh organisasiatau instansi tersebut.

Sedangkan "penertiban Pedagang Kakilima (PKL) oleh SatpolPP Kecamatan Serpong adalah sesuai dengan peraturan yang berlaku dan diselenggarakan oleh Pemerintah Daerah.'Pada penelitian ini, peneliti menggunakann indikator yang digunakan sebagai tolakukur kinerja antara lain effectiveness, responsiveness, responsibility dan accountability.

\section{F. Kerangka Pikir}

Kinerja Satpol PP Kecamatan Serpong dipengaruhi oleh dua faktor, yaitu faktor internal dan faktor eksternl. Faktor-faktor internal yang mempengaruhi kinerja SatpolPP Kecamatan Serpong adalah Sumber Daya Manusia (SDM), sarana dan pasarana serta komunikasi. Sedangkan faktor ekstern adalah terkait dengan pelanggaran-pelanggaran yang dilakukan PKL Pasar Serpong, dimana pelanggaran yang terjadi di lapangan sangatlah berpengaruh pada kinerja Unit SatpolPP Kecamatan Serpong.

\section{III.METODE PENELITIAN}

Penelitianini merupakan jenis penelitian deskriptif, yaitu merupakan penelitian yang digunaka untuk memperoleh gambaran yang tepat dan utuh mengenai suatu gejala yang didalamnya juga terdapat data-data,katakatadan gambaran (data kualitas) maupundata angka-angka (data kuantitas). Sedangkan bila dilihat dari metodenya, penelitianini merupakan penelitian kualitatif yang memiliki tujuan untuk mengkaji beberapakasus tertentu dengan cara mendalam dan menyeluruh.

Penelitianini juga menggunakan jenis penelitianlapangan (Field Research), dimana datadikumpulkan langsung dari lapangan yang berupa dataprimer dan data sekunder. Lokasi dari penelitianini adalah Pasar Serpong yang beralamatkan di Jalan Raya Serpong Kecamatan Serpong, Tangerang 
Selatan. Penelitianini juga menggunakan teknik kepustakaan (LibraryResearch) yaitu kegiatan penelitian yang dilakukan dengan penelusuran atau pencarian teoriteori yangterkait dengan penelitianini.

\section{IV.HASIL DAN PEMBAHASAN}

\section{A. Kinerja Satuan Polisi Pamong Praja (SatpolPP) Kecamatan Serpong Dalam Penertiban Pedagang Kaki lima (PKL) di Pasar Serpong}

Dari hasil penelitianini dapat diketahui bahwa kinerja Satpol PP menjalankan tugasnya dalam penertiban PKL di Pasar Serpong belum terlau baik, hal ini dilihat daribeberapa indikator kinerja ataukriteria penilaian, yaitu :

\section{Effectiveness (Efektivitas)} IndikatorEfektifitas digunakan sebagai salahsatu indikator dalam menilai apakah kinerjaorganisasi yang dalam halini adalah Satuan Polisi Pamong Praja (SatpolPP) Kecamatan Serpong apakahsudah mencapai tujuansasaran dan target yang sebelumnya telahditetapkan. Dengan kata lain, sebuah organisasi/perusahaan dapat dikategorikan efektif apabila tujuan dari organisasi dapat tercapai sesuai dengan rencana yang telah ditetapkan sebelumnya. Begitupula sebaliknya, bila organisasi tersebut belum dapat mencapai tujuan atau sasaran yang telah ditetapkan sebelumnya maka organisasi tersebut dapat dikatakan belum efektif.

Target dari SatpolPP Kecamatan Serpong dalam penertiban Pedagang Kakilima adalah sesuai dengan yang tertuang dalam Peraturan Daerah No.9 Tahun 2012 yaitu mengenai Ketertibanumum. Salah satunya adalah penertiban Pedagang KakiLima (PKL) yang menyalahi aturan. Dalam Perda No.9 Tahun 2012 tentang Ketertibanumum, bagi siapapun dilarang melakukan aktivitas perdagangan di trotoar, badan jalan dan fasilitas umum lainnya.

Pencapaian target ini secara umum masih belum maksimal, hal ini dikarenakan masih ada PKL yang melakukan kegiatan perdagangan di trotoar, badan jalan dan fasilitas umum lainnya di sekitar Pasar Serpong. Hal tersebut juga disebabkan oleh SumberDaya Manusia (SDM) yang dimilikioleh Unit SatpolPP Kecamatan Serpong dirasa masih kurang dari sisi kuantitas. Dimana jumlah pegawai SatpolPP Kecamanatan Serpong keseluruhan hanya berjumlah 17 orang. Kurangnya SDM ini ternyata membawa dampak yang kurang baik bagi pelaksanaan penertiban PKL di Pasar Serpong. 
Kualifikasi pendidikan SDM di SatpolPP Kecamatan Serpong terdiri dari 17 orang teridiri atas 1orang S1, 1orang D3, 13orang SLTA, dan 2 orang SLTP. Dilihat dari kualifikasi pendidikan SDM SatpolPP Provinsi Banten masih didominasi pendidikan SMA. Hal ini menunjukkan dilihat dari sisi kebutuhan pemahaman tugas yang semakin berat diperlukan peningkatan kualitas pendidikan maupun kompetensi SDM yang diharapkan dapat mengimbangi dinamika tugas SatpolPP sebagai aparat penyelenggara ketertibanumum, ketentaraman dan perlindungan masyarakat serta penegak perda dan peraturan pelaksanaannya.

Selain kurangnya SDM, dalam hal sarana dan prasarana di unit SatpolPP Pasar Serpong juga dirasa masih kurang. Untuk menunjang operasional dalam rangka pelaksanaan tugas dan fungsinya dengan dukungan sarana mobilitas sebanyak 2 buah kendaraan, terdiri dari 1 kendaraan roda 4 (empat) dan 2 kendaraan roda 2 (dua). Kondisi kendaraan yang ada masih dapat digunakan seluruhnya dalam mendukung pelaksanaan tugas aparat Satpol PP, namun kondisinya sudah tidak layak. Selain kendaraan operasional, dalam menunjang pelaksanaan tugas dan fungsinya,Satpol PP difasilitasi dengan sejumlah peralatan operasional lainnya yang terdiri dari 5 buah Gegep (Tang), 1 buah tangga alumunium, 6 buah tameng, 2 buah lampu lalu lintas dan 2 buah handy talky. Kondisi peralatan sudah tidak layak digunakan terutama alat komunikasi dalam menunjang pelaksanaan tugas dilapangan, dan peralatan untuk mendukung pelaksanaan tugas yang mendadak di SatpolPP Kecamatan Serpong belum memiliki maka perlu adanya pemeliharaan secara rutin dan pengadaan peralatan khususnya untuk penanganan tugas yang bersifat mendadak, dan perlu ada pembelian peralatan baru.

\section{Responsibility}

(Responsibilitas)

Penilaian Kinerja dalam suatu organisasi merupakan deskripsi mengenai tingkat pelaksanaan suatu programatau kegiatan dalam suatu organisasi dalam mewujudkan visi, misi serta tujuan dari seebuah organisasi. IndikatorResponsibilitas adalah salahsatu indikator yang dapat menilai kinerjasuatu organisasi. IndikatorResponsibilitas merupakan suatucara dalam 
melihatapakah sebuah organisasi melaksanakan kegiatannya telah sesuai dengan peraturan yang sudahada.

Dalam rangka menegakan Peraturan Daerah dan pemeliharaan ketertiban umum serta ketentraman masyarakat, SatpolPP selalu mengikut sertakan aparat Penegak Hukum terutama dengan Kepolisian di Tingkat Daerah, OPD Provinsi dan dengan Satuan Polisi Pamong PrajaKabupaten/Kota serta OPD Kabupaten/Kota .Tindakan aparat SatpolPP dalam menindak para pelanggar dapat dikelompokkan menjadi 3 bagian yaitu sebagai berikut :

- Upaya / Tindakan Preventif (Persuasif)

Upaya/ Tindakan Preventif yang seharusnya diterapkan personil SatpolPP berdasarkan Perda nomor 54 tahun 2011 adalah sebagai berikut: "membentuk peraturan-peraturan yang berlaku yang berhubungan dengan sistem prosedur, hubungan dan tata kerja, membuat pedoman/ manual sampai dengan peraturan yang ditetapkan, membentuk kedudukan, tugas, wewenang dan $\begin{array}{lr}\text { tanggung } & \text { jawab, } \\ \text { mengorganisasi } & \begin{array}{r}\text { segala } \\ \text { macam }\end{array} \\ \text { kegiatan, }\end{array}$ penempatan, pengawasan dan pembagian pekerjaan, membentuk sistem koordinasi, pelaporan dan pemeriksaan." Dalam pelaksanaan yang ada di lapangan, upaya / tindakan preventif yang telah dilaksanakan adalah dilakukan penyuluhan dan pendekatan secara persuasif satu bulan sekali. Pada tahap ini, personil Satpol PP seperti diskusi dan pertukaran pendapat.

- Upaya Represif (Penindakan)

Dilakukan oleh Kepala Pasar dalam mencari lokasi untuk relokasi Pedagang Kaki lima. Relokasi yang disediakan untuk PKL pasar Serpong adalah bertempat di dekat stasiun Kereta Api Serpong (100 meter dari pasar Serpong)

- Upaya Pengawasan Memberikan sanksi terhadap penyimpangan dari peraturan. Apabila masih ada pelanggaran oleh PKL maka akan dilkukan tindakan penghalauan, jika tahap ini 
masih dilanggar akan diberikan teguran lisan maupun tertulis. Jika terbukti masih melakukan pelanggaran akan diberikan tindakan non yustisial maupun secara yusticial perkaranya akan dilimpahkan ke pengadilan. (Hampir semua pengawasan tindakan dilaksanakan. Tindakan yang belum dilaksanakan adalah memberikan sanksi terhadap penyimpangan dari peraturan)

Selain melakukan upaya-upaya tersebut, Dalam menegakkan ketertiban dan ketentraman SatpolPP menerapkan Standar Oprasional Prosedur dalam kegiatan yang dilakukan. Standar Operasional Prosedur (SOP) adalah dokumen yang berkaitan dengan prosedur yang dilakukan secara kronologis untuk menyelesaikan suatu pekerjaan yang bertujuan untuk memperoleh hasil kerja yang paling efektif dari para pekerja dengan biaya yang serendah-rendahnya.

\section{Responsiveness}

Responsivitas juga merupakan salah satuindikator dalammenilai kinerja dalam sebuah organiasi.
Responsivitas merupakan sikap providerdalam mengatasi komplan, masukan saran, kritik dankeluhan dari masyarakat. Responsivitas merupakan kemampuan organisasi untuk mengenali kebutuhan masyarakat, menyusun agendadan prioritas pelayanan dan mengembangkan program-programdalam suatu pelayanan publik yang sesuai dengan kebutuhan dan aspirasi masyarakat.

Indikatorresponsivitas dapat diukur dari ada tidaknya saluran komunikasibagi warga masyarakat untuk menyampaikan aspirasi atau keinginannya. Saluran komunikasi ini sangat diperlukan bagi masyarakatagar mereka dapat menyalurkan aspirasi atau kebutuhan yangdiharapkan, sedangkan bagi organisasi SatpolPP Kecamatan Serpong merupakan sarana untuk menerima saran, kritik dan keluhan masyarakat.

Berdasarkan hasilpenelitian terhadap kinerja UnitSatpolPP Kecamatan Serpong diketahui bahwa indikator responsivitas sudah baik. Halini dapaat dilihat pada pengukuran terhadapkeluhan, kritik dansaran yang telah diterima dengan baik oleh Unit SatpolPP Kecamatan Serpong. Masyarakat khususnya para Pedagang 
KakiLima (PKL) dapat memberikan keluhan mereka terhadapUnit SatpolPP Kecamatan Serpong. Keluhan yang disampaikan dengan cara menghadiri perkumpulan antara Pedagang Kaki lima di Pasar Serpong.

\section{Accountability (Akuntabilitas)}

Akuntabilitas publik menunjuk pada bagaimana penyelenggaraan pelayana publik dapat dipertanggung jawabkan kepada publik maupun kepada pemerintah. Akuntabilitas yang dilakukan apakah sudah sesuai dengan peraturan perundangundangan yang berlaku ataukah belum. Akuntabilitas dapat disimpulkan sebagai kewajiban seseorang atau unit organisasi untuk mempertanggung jawabkan pngelolaan dan pengendalian sumber daya dan pelaksanaan kebijakan yang dipercayakan kepadanya dalam rangka pencapaian tujuan yang telah ditetapkan melalui media pertanggung jawaban secara periode.

Dalam pelaksanaan penegakan peraturan daerah, SatpolPP harus memiliki tanggung jawab terhadap apayang mereka kerjakan. Apabila tidak memiliki rasa tanggung jawab yangtinggi terhadap pekeraan yang akan mereka jalani, maka akan ada bentuk penyalah gunaan wewenang dalam pekerjaan yang akan dilakukan serta akan menjalanka tugas mereka secara tidak sesuai dengan Tupoksi yang ada.

Dari hasil yang didapat,
diketahui bahwa
menjalankan Peraturan Daerah, Satpo 1PP Kecamatan Serpong telah menjalankan sesuai dengan mutu yang baik, estimasi waktu yang tepat serta prosedur yang mudah diterima serta dipahami oleh masyarakat. Hal tersebut diungkap oleh beberapa aparatur Satpol PP yang menjalankan penegakkan Peraturan Daerah tersebut dengan prosedur yang baik berdasarkan SOP (Standar Operasional Prosedur) dan sasaran kerja yang mereka miliki agar dalam menjalankan Peraturan Daerahtidak menyimpang karena dikerjakan berdasarkan SOP yang ada.

B. Faktor-faktor Yang Mempengaruhi Kinerja Unit Satpo IPP Kecamatan Serpong Dalam Penertiban PKL di Pasar Serpong

Kinerja Satpol PP Kecamatan Serpong dalam penertiban PKL di Pasar Serpong dipengaruhi oleh 3 
faktor, yaitu : faktor SDM, faktor sarana dan prasarana dan faktor komunikasi.

1. Faktor Sumber Daya Manusia (SDM)

Jumlah SDM keseluruhan yang ada di Satpol PP Kecamatan Serpong per Februari 2014 adalah sebanyak 17 orang terdiri atas 1 orang Kasi, 2 orang staf PNS dan 14 non PNS. Penentuan jumlah personil disesuaikan dengan analisa beban kerja dan hal ini sudah dilakukan. Satpol PP Kecamatan Serpong senantiasa melakukan koordinasi dengan Badan Kepegawaian Daerah Provinsi Banten untuk melakukan penambahan personil. Sementara dengan SDM yang ada, SatpolPP berupaya untuk meningkatkan kualitas aparatnya melalui berbagai pendidikan dan pelatihan yang diharapkan dapat meningkatkan kualitas pengetahuan, keterampilan, sikap dan membentuk perilaku Polisi Pamong Praja, sesuai dengan Peraturan Menteri Dalam Negeri Nomor 38 Tahun 2010 tentang Pedoman Penyelenggaraan Diklat Dasar Polisi Pamong Praja.

Untuk meningkatkan kualitas SDM Satpol PP dilakukan upayaupaya yaitu Pendidikan dan pelatihan dasar, bentuk pembinaan kualitas personil serta berbagai kegiatan rutin yang dilakukan oleh SatpolPP, diantaranya kegiatan kesemaptaan yaitu untuk menjaga kebugaran anggota melalui olahraga dan pelatihan baris berbaris, kegiatan pembinaan teknis anggota SatpolPP sebagai aparat penegak Peraturan Daerah dan peraturan serta mengikutsertakan anggota SatpolPP dalam bimbingan teknis maupun seminar dan rapat kerja.

Kualifikasi pendidikan SDM di SatpolPP Kecamatan Serpong terdiri dari 17 orang teridiri atas 1orang S1, 1orang D3, 13orang SLTA, dan 2orang SLTP. Dilihat dari kualifikasi pendidikan SDM Satpol PP Kecamatan Serpong masih didominasi pendidikan SLTA . Hal ini menunjukkan dilihat dari sisi kebutuhan pemahaman tugas yang semakin berat sehingga diperlukan peningkatan kualitas pendidikan maupun kompetensi SDM yang diharapkan dapat mengimbangi dinamika tugas SatpolPP sebagai aparat penyelenggara ketertibanumum, ketentaraman dan perlindungan masyarakat serta penegak perda dan peraturan pelaksanaannya.

2. Faktor Sarana dan Prasarana Untuk menunjang operasional dalam rangka pelaksanaan tugas 
dan fungsinya dengan dukungan sarana mobilitas sebanyak 2 buah kendaraan, terdiri dari 1 kendaraan roda 4 (empat) dan 2 kendaraan roda 2 (dua). Kondisi kendaraan yang ada masih dapat digunakan seluruhnya dalam mendukung pelaksanaan tugas aparat Satpol PP, namun kondisinya sudah tidak layak. Oleh karena itu diperlukan penggantian kendaraan operasional tersebut.

Selain kendaraan operasional, dalam menunjang pelaksanaan tugas dan fungsinya. SatpolPP difasilitasi dengan sejumlah peralatan operasional lainnya yang terdiri dari 5 buah Gegep (Tang), 1 buah tangga alumunium, 6 buah tameng, 2 buah lampu lalu lintas dan 2 buah handy talky. Kondisi peralatan sudah tidak layak digunakan terutama alat komunikasi dalam menunjang pelaksanaan tugas dilapangan, dan peralatan untuk mendukung pelaksanaan tugas yang mendadak di SatpolPP Kecamatan Serpong belum memiliki maka perlu adanya pemeliharaan secara rutin dan pengadaan peralatan khususnya untuk penanganan tugas yang bersifat mendadak, dan perlu ada pembelian peralatan baru.
3. Faktor Komunikasi

Komunikasi adalah suatu proses dimana seseorang atau beberapa orang, kelompok, organisasi menciptakan komunikasi dan menggunakan informasi merupakan faktor penting dalam organisasi untuk menciptakan interaksi timbal balik internal organisasi dan eksternal organisasi. Kinerja Unit Satpol PP Kecamatan Serpong dipengaruhi oleh faktor komunikasi yaitu komunikasi antar pegawai dan komunikasi antara Unit Satpol PP dengan PKL dan masyarakat. Unit SatpolPP Kecamatan Serpong memiliki kendala komunikasi eksternal organisasi seperti kesalahan komunikasi antara Unit SatpolPP dengan PKL terkait dengan penertiban lokasi dagang.

Faktor komunikasi selanjutnya terkait dengan fasilitas komunikasi yang dimiliki Unit SatpolPP Kecamatan Serpong seperti jaringan internet dan alat komunikasi. Unit SatpolPP Kecamatan Serpong memiliki kendala dalam proses komunikasi dengan instansi lain dan masyarakat sperti pengiriman data-data dan informasi via email. Mengingat pentingnya internet bagi organisasi maka kedepannya perlu sekali perhatian terhadap 
pengadaan jaringan internet tersebut.

\section{KESIMPULAN DAN SARAN}

\section{A. KESIMPULAN}

Berdasarkan hasil penelitian yang dilakukan dengan judul Kinerja Satuan Polisi Pamong Praja (SatpolPP) Kecamatan Serpong Dalam Penertiban Pedagang Kakilima (PKL) di Pasar Serpong, peneliti menarik kesimpulan, yaitu :

1. Kinerja SatpolPP Kecamatan Serpong dalam penertiban PKL di Pasar Serpong dilihat masih kurang maksimal. Hal inidilihat dari hasil pengukurankinerja yang terdiri dari 4 indikator masih ada yang kurang. Pada indikator effectiveness hasilnya masih kurang baik dikarenakan pencapaian target SatpolPP Kecamatan Serpong masih belum tercapai. Masih banyaknya PKL yang berjualan di trotar / badan jalan di sekitar Pasar Serpong membuat kondisi lingkungan sekitar menjadi kurang nyaman dan kurang tertib. Untuk 3 indikator lainnya sudah baik seperti pada indikator responsibility, Unit SatpolPP Kecamatan Serpong telah melakukan sosialisasi kepada PKL di Pasar Serpong. Sosialisasi tersebut terkait dengan penertiban PKL di kawasan Pasar Serpong. Selanjutnya untuk indikator responsivitas, hasil terhadap kinerja SatpolPP Kecamatan Serpong sudah baik berdasarkan pengukuran terhadap keluhan, kritikdan saran yang diterma dengan baik oleh Unit SatpolPP kecamatan Serpong. Indikator terakhir adalah accountability, hasilnya adalah sudah baik. Hal ini dapat diketahui bahwa dalam menjalankan penegakkan Peraturan Daerah, SatpolPP Kecamatan Serpong menjalanka sesuaidengan mutu yang baik, estimasiwaktu yang tepat serta proseduryang mudah dipahami oleh masyarakat.

2. Satuan Polisi Pamong Praja sudah melakukan upaya - upaya dalam penataan PKL pada pasar serpong, sesuai dengan tugas pokoknya membantuWalikota dalam melaksanakan Pemerintahan di Bidang Ketentramandan Ketertiban masyarakat serta penegakan Perda nomor 9 tahun 2012. Upaya yang dilakukan adalah sebagai berikut:

a. Upaya / Tindakan Preventif (Persuasif)

- Membentuk peraturan peraturan yang berlaku yang berhubungan dengan sistem prosedur, hubungan dan tata kerja 


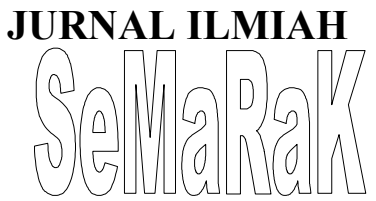

- Membentuk kedudukan, tugas, wewenang dan tanggung jawab.

- Mengorganisasi segala macam kegiatan, penempatan, pengawasan dan pembagian pekerjaan

- Dalam pelaksanaan yang ada di lapangan, upaya / tindakan preventif yang telah dilaksanakan adalah dilakukan penyuluhan dan pendekatan secara persuasif satu bulan sekali. Pada tahap ini, personil SatpolPP seperti diskusi dan pertukaran pendapat.

b. Upaya Represif (Penindakan) Dilakukan oleh Kepala Pasar dalam mencari lokasi untuk relokasi Pedagang Kakilima. Tempat relokasi yang disediakan untuk PKL Pasar Serpong berada di dekat Stasiun Kereta Api Serpong (100m dari pasar Serpong).

a. Upaya Pengawasan

Memberikan sanksi terhadap penyimpangan dari peraturan. Apabila masih ada pelanggaran oleh PKL maka akan dilkukan tindakan penghalauan, jika tahap ini masih dilanggar akan diberikan teguran lisan maupun tertulis. Jika terbukti masih melakukan pelanggaran akan diberikan tindakan non yustisial maupun secara yusticial perkaranya akan dilimpahkan ke pengadilan

(Hampir semua tindakan pengawasan telah dilaksanakan. Tindakan yang belum dilaksanakan adalah memberikan sanksi terhadap penyimpangan dari peraturan)

\section{B. SARAN}

1. Saran ditujukan kepada Unit Satpol PP Kecamatan Serpong dalam rangka meningkatkan kualitas SDM dan kemampuan teknis operasional di lapangan dengan mengadakan diklat-diklat teknis serta meningkatkan kualitas pendidikan dari personel SatpolPP Kecamatan Serpong.

2. Pemerintah kota sebaiknya menyediakan sarana dan prasarana yang lebih memadai bagi SatpolPP. Seperti penambahan jumlah kendaraan patroli, perawatan kendaraan patroli dan penggantian kendaraan yang kondisinya sudah tidak layak pakai. Selain itu, pemerintah sebaiknya menambah jumlah peralatan operasional agar dalam melaksanakan tugas dan fungsinya, SatpolPP dapat menjalankannya dengan baik. 
JURNAL ILMIAH

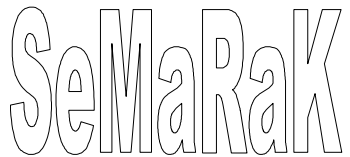

DAFTAR PUSTAKA

Abidin, Said Zainal. 2006. Kebijakan Publik Edisi Revisi Cetakan Ketiga. Jakarta : Suara Bebas

Arikunto, Suharsimi. 2006. Prosedur Penelitian Suatu Pendekatan Praktik. Jakarta: PT. Rineka Cipta.

Bagong, Suyanto, dkk. 2005. Menata PKL dan Bangunan Liar. Surabaya: Pemkot Surabaya, Badan Penelitian dan Pengembangan Kota Surabaya

Diding Nurdin.2009.Dasar-Dasar Pengembangan

Kurikulum.Bandung : PT Remaja Rosdakarya

Djohar, As'ari. 2009. Pendidikan Teknologi dan Kejuruan. Dalam Ali, M., Ibrahim, R., Sukmadinata, N.

Georgopolous, Tannembaum.1985. Efektivitas Organisasi. Jakarta: Erlangga

Harmuni. 2012. Strategi Pembelajaran. Yogyakarta: Insan Madani

Hasibuan, Malayu S.P. 2010.Manajemen Sumber Daya Manusia. Jakarta: PT. Bumi Aksara

Krisnaldy, K., Pasaribu, V. L. D., \& Senen, S. (2019). PENGARUH BUDAYA ORGANISASI, LINGKUNGAN KERJA DAN IKLIM ORGANISASI TERHADAP
MOTIVASI PEGAWAI SERTA DAMPAKNYA TERHADAP KEPUASAN KERJA. Jurnal Semarak, 2(2).

Martini, Lubis. 1997. Teori Organisasi. Bandung: Ghalia Idonesia Miles, B Matthew \& A. Michael Huberman. 1992. Analisis Data kualitatif (Terjemahan Teecep Rohendi). Jakarta: UI Press

Moleong, Lexy. 2006. Metodologi Penelitian Kualitatif. Bandung: PT. Remaja Rosda Karya

Nasution. 2003. Metode Penelitian Naturalistik Kualitatif. Bandung: Tarsito

Nina Rahmayanti.2010.Manajemen Pelayanan

Prima.Yogyakarta: Graha Ilmu

Nugroho, Riant.D. 2003. Kebijakan Publik

(ImplementasidanEvaluasi).

Jakarta : Elex Media Komputindo

Pasaribu, V. L. D., \& Krisnaldy, K. (2018). ANALISIS KEPUASAN JAMA'AH PADA KINERJA DEWAN KEMAKMURAN MASJID ALHIDAYAH PERIODE TAHUN 2017. KREATIF: Jurnal Ilmiah Prodi Manajemen Universitas Pamulang, 6(4), 41-51. 
JURNAL ILMIAH

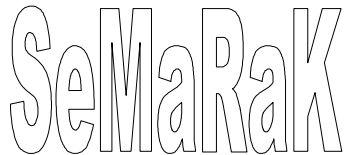

P-ISSN 2615-6849, E-ISSN 2622-3686

Jurnal Semarak,Vol. 3,No.1, Februari 2020, Hal (1- 19)

@Prodi Manajemen Fakultas Ekonomi Universitas Pamulang

Pasaribu, V. L. D., Krisnaldy, K., \& Himpunan Peraturan PerundangWarasto, H. N. (2020). Pengaruh Undangan.2011. Satuan Polisi Pamong Gaya Kepemimpinan, Disiplin Kerja Dan Kompensasi Terhadap Kinerja Pegawai (Studi kasus kelurahan Pisangan Ciputat). Disrupsi Bisnis, 3(1).

Samsudin.2010.Manajemen Sumber adaya Manusia.Bandung: Pustaka Setia

Sarwoto.1990. Dasar-Dasar Organisasi Manajemen. Jakarta: Praja (SatpolPP) dan Peraturan Pelaksanaannya. Bandung: Fokusmedia

UU Republik Indonesia Nomor 32 Tahun 2004 Tentang Pemerintahan Daerah pada Pasal 1 ayat (2) dan pada Pasal 148 ayat (1)

Peraturan Pemerintah Republik Indonesia Nomor 32 Tahun 2004 Tentang Satuan Polisi Pamong Praja Ghalia Indonesia

Peraturan Menteri Dalam Negeri Nomor

Steers. 1985. Variabel dalam Organisasi. Jakarta: Bima Kencana.

Sugiyono. 1999. Metode Penelitian Administrasi. Bandung: Alfabeta.

\section{Undang-Undang dan Perda}

Himpunan Peraturan PerundangUndangan.2010. Satuan Polisi Pamong Praja (SatpolPP) dan Peraturan Pelaksanaannya. Bandung: Fokusmedia
26 Tahun 2005 Tentang Prosedur Tetap Operasional Satuan Polisi Pamong Praja

Peraturan Menteri Dalam Negeri Nomor 38 Tahun 2010 Tentang Pedoman Penyelenggaraan Diklat Dasar Polisi Pamong Praja. 